\title{
THE METAPHOR OF CELEBRITY
}

Canadian Poetry and the Public, 1955-1980 
This page intentionally left blank 


\section{The Metaphor of Celebrity}

Canadian Poetry and the Public, 1955-1980

JOEL DESHAYE

UNIVERSITY OF TORONTO PRESS

Toronto Buffalo London 
(C) University of Toronto Press 2013

Toronto Buffalo London

www.utppublishing.com

Printed in Canada

ISBN 978-1-4426-4661-2

6

Printed on acid-free, $100 \%$ post-consumer recycled paper with vegetable-based inks.

\section{Library and Archives Canada Cataloguing in Publication}

Deshaye, Joel, 1977-

The metaphor of celebrity : Canadian poetry and the public, 1955-1980 / Joel Deshaye.

Includes bibliographical references and index.

ISBN 978-1-4426-4661-2 (bound)

1. Canadian poetry - 20th century - History and criticism. 2. Poets, Canadian Public relations. 3. Poetry - Social aspects. 4. Authors and readers Canada - History - 20th century. 5. Influence (Literary, artistic, etc.) History - 20th century. 6. Identity (Psychology). I. Title.

PS8153.D47 $2013 \quad$ C811'.509 C2013-903482-X

University of Toronto Press acknowledges the financial assistance to its publishing program of the Canada Council for the Arts and the Ontario Arts Council.

Canada Council

Conseil des Arts for the Arts du Canada

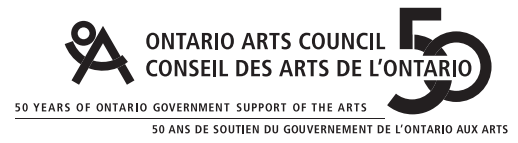

This book has been published with the help of a grant from the Canadian Federation for the Humanities and Social Sciences, through the Awards to Scholarly Publications Program, using funds provided by the Social Sciences and Humanities Research Council of Canada.

University of Toronto Press acknowledges the financial support of the Government of Canada through the Canada Book Fund for its publishing activities. 